\title{
Pilietinis pasipriešinimas Lietuvos saugumo ir gynybos sistemoje: raida ir perspektyvos
}

\begin{abstract}
Lietuva yra viena iš nedaugelio valstybiu pasaulyje, kurios saugumo ir gynybos strategijoje šalia karinès gynybos svarbus vaidmuo skiriamas pilietiniam pasipriešinimui (pilietinei gynybai). Straipsnyje nagrinejjamos istorinès aplinkybès bei teorinès prielaidos, lèmusios Lietuvos politinio elito dèmesị šiai netradicinei gynybos formai. Pirmiausiai trumpai apžvelgiama pilietinès gynybos teorijos raida bei nagrinèjamos kai kurių jos elementu taikymo ypatybès Lietuvos išsivadavimo judejjime (1990-1991 m.). Po to analizuojama pilietinio pasipriešinimo bei pilietinès gynybos samprata Lietuvos saugumo ir gynybos politika reglamentuojančiuose dokumentuose. Galiausiai, vertinant pilietinio pasipriešinimo vietą ir perspektyvas šiuolaikineje Lietuvos saugumo sistemoje, daroma išvada, kad euroatlantinès integracijos ir globalizacijos sąlygomis visuotinis pilietinis pasipriešinimas, siejamas su pilietinių laisvių išsaugojimu, nepraranda aktualumo, išlikdamas universaliu atsaku ị bet kokias grèsmes.
\end{abstract}

\section{Ivadas}

Lietuvos Nacionalinio saugumo strategijoje (2002) pažymima, kad „valstybės gynyba susideda iš karinio saugumo ir pilietinio pasipriešinimo“" . Dokumente nurodoma, kad pilietinis pasipriešinimas apima ginkluotas (partizaninis karas) ir neginkluotas (įvairios pilietinio nepaklusnumo akcijos) civiliu gyventojų rezistencijos formas, kurios turètų būti taikomos šalies okupacijos atveju. Pilietinis pasipriešinimas, suprantamas kaip spontaniškas civilių gyventojų įijungimas į valstybẻs gynybą, yra gana plačiai aprašytas įvairiuose istoriniuose šaltiniuose, tačiau jo potencialo išankstinis įkomponavimas ị gynybos strategiją yra retas dalykas. Ryškiausiais šiuolaikiniais tokio ịkomponavimo pavyzdžiais galima laikyti Šveicarijos ir Švedijos visuotinès gynybos koncepcijas.

\footnotetext{
"Doc., dr. Gražina Miniotaité - Lietuvos karo akademijos Politikos mokslų katedros docentẻ ir Kultūros, filosofijos ir meno instituto mokslo darbuotoja. Adresas: Šilo 5a, 10322 Vilnius, tel. 8-52103569, e-paštas: grazinam@ktl.mii.lt

${ }^{1}$ Nacionalinio saugumo strategija, 2002, 5.2.3.2 http://www.kam.lt/catalog/ministerija/nacionalinio_saugumo_strategija_06_05.doc, 20030801.
} 
Mėginant pilietiniam pasipriešinimui surasti vietą gana plačiame gynybos konceptualizavimo spektre, išryškejja teorinis sąvokos neapibrèžtumas, jos konceptualinių pagrindų prieštaringumas. Kyla nemaža klausimų: ar galima pilietinị pasipriešinimą laikyti savarankiška alternatyvia gynybos forma, ar tai tik tam tikras karinès gynybos priedas; koks santykis tarp karinès gynybos ir pilietinio pasipriešinimo; ar strategiškai suderinamas ginkluotas partizaninis karas ir ịvairios neginkluoto pasipriešinimo akcijos? Tam tikrus mėginimus atsakyti ị šiuos klausimus randame neprovokuojančios gynybos ${ }^{2}$ (ang. non-provocative defence) ir pilietinès gynybos (ang. civilian defence) koncepcijose. Bendra šioms koncepcijoms yra tai, kad jų didžiausio populiarumo laikotarpis - Šaltojo karo metai. Jas vienija mėginimas surasti alternatyvias, neprovokuojančias priešininko gynybos formas bei dèmesys bendro saugumo ir pasitikejjimo tarp valstybių stiprinimo klausimams ${ }^{3}$.

Neprovokuojančios gynybos doktrinos prielaida yra neorealistinė saugumo dilemos interpretacija ${ }^{4}$. Kaip pažymi Robert Jervis, anarchinėje tarptautinejje sistemoje ginklavimasis gynybos tikslais kitų valstybių gali būti interpretuotas kaip ginklavimasis puolimo tikslais ir sukelti atsakomuosius veiksmus. Norint išvengti saugumą destabilizuojančio poveikio, reikia vystyti neprovokuojančią, atvirą gynybinę saugumo sistemą ${ }^{5}$. Neprovokuojančios gynybos koncepcija yra siejama su tokiomis idejomis, kaip kolektyvinis saugumas, taikos palaikymas (ang. peace keeping), pasitikèjimo kūrimas (ang. confidence building). Ypač perspektyvi neprovokuojančios gynybos idejja atrode XX a. devintojo dešimtmečio pradžioje. Tačiau, kaip rodo mažejantis publikacijų skaičius, susidomëjimas ja palaipsniui blèsta ${ }^{6}$.

Pilietinès gynybos koncepcija gali būti traktuojama kaip specifinis neprovokuojančios gynybos atvejis ${ }^{7}$. Ji dar vadinama piliečiais grindžiama gynyba (ang. civilian-based defence), socialine gynyba (ang. social defence), neprievartine gynyba (ang. nonviolent defence) bei gynyba pilietiniu pasipriešinimu (ang. defence by civil resistance $)^{8}$. Šiomis iš esmès gana panašiomis sąvokomis mėginama konceptualizuoti tam tikrą valstybės gynimo būdą, kurio pagrindą sudaro gyventojų sugebẻjimas

\footnotetext{
${ }^{2}$ Neprovokuojanti gynyba dar vadinama ginamaja gynyba (ang. defensive defence), nepuolamaja gynyba (ang. non-offensive defence), teritorine gynyba (ang. territorial defence), gynybiniu atgrasy$\mathrm{mu}$ (ang. defensive deterrence), konvenciniu atgrasymu (ang. conventional deterrence) ir alternatyvia gynyba (ang. alternative defence) Žr.: Wiseman G., Concepts of Non-provocative Defence: Ideas and practices in international security, New York: PALGRAVE, 2002, p. 3-4; Moller B., Dictionary of Alternative Defence, Boulder, CO: Lynne Rienner, 1995.

${ }^{3}$ Neprovokuojančios gynybos idejjų vystymui ypatingai reikšminga buvo Švedijos ministro pirmininko Olof Palme vadovaujamos tarptautinès Nepriklausomos nusiginklavimo ir saugumo klausimu komisijos (Independent Commission on Disarmament and Security Issues, 1982) veikla.

${ }^{4}$ Moller B., Common security and Nonoffensive Defense: A Neorealist Perspective, Boulder, CO: Lynne Rienner, 1992.

5 Jervis R., Perception and Misperception in International Politics, Princeton, NJ: Princeton University Press, 1976, p. 64-65.

${ }^{6}$ Nors plačiai diskutuojama bei palaikoma viešosios nuomonès, neprovokuojančios gynybos idėja netapo vyraujančio strateginio mąstymo dalimi net ir jos didžiausio populiarumo laikotarpiu. Jos šalininkai buvo siejami su taikos, o ne prestižinemis strategijos studijoms, dažniausiai išreikšdami opozicijos, o ne vyriausybès požiūrị.

7 Wiseman, (note 2) p. 10.

${ }^{8}$ Brian M., „Social Defence Strategy: the Role of Technology“, Journal of Peace Research, 5 (26), 1999 , p. 535-552.
} 
neprievartiniais metodais sustabdyti grèsmes, iškilusias jų fundamentalioms laisvėms ${ }^{9}$. Tai - ne teritorinè gynyba, o pagrindinių socialinių vertybiu (laisvès, nepriklausomybès, demokratijos, taikos) ir socialinės struktūros, palaikančios šias vertybes, gynimas ${ }^{10}$.

Pilietinio pasipriešinimo sąvokoje persipina ir neprovokuojančios teritorinès gynybos, ir pilietinès gynybos doktrinų elementai. Tai sudaro prielaidas tam tikram konceptualiam nenuoseklumui, kuris pasireiškia mėginimais suderinti pozityviai orientuotą realiają santykių tarp valstybių sampratą ir gandiškaji normatyvizmą ${ }^{11}$. Apskritai pilietinio pasipriešinimo sampratos vystymas ir pagrindimas yra labiau sietinas su pilietinės gynybos negu neprovokuojančios gynybos koncepcija. Neprovokuojančios gynybos doktrinos dėmesio centre - karinès gynybos analizé, nukreipta ị saugumo dilemos sušvelninimą, tuo tarpu pilietinès gynybos teoretikus pirmiausiai domina civilių gyventojų panaudojimo galimybés valstybės gynyboje. Tad straipsnyje daugiausiai remiamasi pilietinès gynybos koncepcijos įžvalgomis.

Idẻja apie pilietinio pasipriešinimo panaudojimą valstybès gynyboje atsirado po I Pasaulinio karo Nyderlanduose, karo veteranų aplinkoje. Tai buvo greičiau neapykantos karui išraiška, noras surasti būdus, tausojančius aplinką bei gyventojus, negu teoriškai pagrịsta idèja. Ji atgimé po II Pasaulinio karo, ypač Šaltojo karo laikotarpiu. 1964 m. šiai idėjai plètoti įvyko I tarptautinė konferencija Oksforde.

Netrukus pasirodè mokslinių publikacijų, nagrinėjančiu pilietinès gynybos perspektyvas Vakarų Europoje ${ }^{12}$. Žinomas karinès strategijos specialistas Basil LiddellHart, mėgindamas pagrịsti valstybės gynybos strategiją atominio karo grèsmès aplinkybẻmis, pabrèžè, kad dabartinėje tankiai apgyvendintoje miestų Europoje kova prieš okupaciją negali orientuotis i i ginkluotą pasipriešinimą, - tai turètų būti nekariné gynyba ${ }^{13}$. Vokietijoje broliai Hans Heinrich ir Wilhelm Nolte suformulavo autonominės gynybos koncepciją, teigiančią, kad atominès grèsmès akivaizdoje šalis turi kliautis savo jègomis, o ne kolektyvinės gynybos sistemomis. Jie ypač pabrèžè, kad autonominė gynybos sistema turi atsižvelgti ị konkrečios šalies specifiką, sistemoje turi būti išradingai derinama karinè ir pilietinė gynyba ${ }^{14}$. Autonominės gynybos idèją gana palankiai prièmè kai kurių Europos šalių, daugiausiai nedidelių valstybių, karinis ir politinis elitas. Ją į savo gynybos doktrinąi itraukẻ Belgija, Nyderlandai, Švedija, Prancūzija, Šveicarija ${ }^{15}$.

\footnotetext{
${ }^{9}$ Низинг Й., Общесмвенная оборона как логичеслая альмернамива, Москва: СЕРСО, 1993, p. 146 (Niezing J., Sociale verdegiging als logisch alternatief, Antwerpen - Assen / Maastricht, 1987).

${ }^{10}$ Geeraerts, G., „Two approaches to civilian defence" in Geeraerts G., ed., Possibilities of Civilian Defence in Western Europe, Amsterdam: Swets \& Zeitlinger, 1976, p. 6.

${ }^{11}$ Apie Mahatmos Gandžio idejju įtaką pilietinès gynybos koncepcijai žr.: Sharp G., Gandhi as a Political Strategist, with Essays on Ethics and Politics, Mass.: Porter Sargent, 1979.

${ }^{12}$ Roberts A., ed., The Strategy of Civilian Defence: Non-violent Resistance to Aggression, London: Faber and Faber, 1967; Boserup A., Mack A., War Without Weapons: Non-violence in National Defence, London: Frances Pinter, 1974; Geeraerts G., ed., Possibilities of Civilian Defence in Western Europe, Amsterdam: Swets and Zeitlinger, 1976; Sharp G., Making Europe Unconquerable: The Potential of Civilian-based Deterrence and Defense, Cambridge, Mass.: Ballinger, 1985.

${ }^{13}$ Liddel - Hart B., Strategy. The Indirect Approach, London: Faber \& Faber Ldt., 4 th revised and further enlarged ed., 1967; Liddell - Hart, B., „Lessons from Resistance Movements, Guerilla and Non-Violence" in Roberts, (note 12) p. 208-210.

${ }^{14}$ Nolte H. H., Nolte W., Ziviler Widerstand und Autonome Abwehr, Baden-Baden, 1984, p. 154.

151972 metais Švedijos vyriausybès užsakymu vienas iš pilietinès gynybos idejjos pradininkų Adam Roberts parengè studiją „Totalinè gynyba ir pilietinis pasipriešinimas“, turejjusią įtakos nacionalinès gynybos sampratai įvairiose šalyse . Žr.: Низинг (note 3) p. 27-30.
} 
Naują impulsą pilietinės gynybos idẻjų plètotei suteikė Sovietų Sajungos žlugimas bei Šaltojo karo pabaiga ${ }^{16}$. Pilietinės gynybos teorijos vystymuisi ypač reikšmingas buvo 1989-1991 m. taikus Rytų Centrinès Europos išsivadavimo nuo Sovietų Sajungos patyrimas, kuriame Lietuvai teko išskirtinis vaidmuo ${ }^{17}$. Kovodama dèl nepriklausomybės Lietuva ne tik taikè pilietinị pasipriešinimą, bet ir oficialiai įvardijo jị kaip valstybės gynybos būdą (1990-1991 m. . $^{18}$. Be to, tapusi suverenia valstybe, neatsisakè šios idèjos, o suteikè jai pakankamai reikšmingą vietą , Nacionalinio saugumo pagrinduose“ (1996) bei „Nacionalinio saugumo strategijoje“(2002). Iš oficialių dokumentų galima spręsti, kad Lietuvos gynyba yra grindžiama visuotinès besąlygiškos gynybos principu, apimančiu karinę ir nekarinę gynybą. Kyla klausimas, ar visuotinès gynybos bei pilietinio pasipriešinimo idejjos atitinka naujas aplinkybes, susijusias su Lietuvos naryste NATO ir ES bei jos įsijungimu ị kolektyvinès gynybos sistemą. Mėginant atsakyti ị ši klausimą, straipsnyje pirmiausiai trumpai apžvelgiama pilietinès gynybos teorijos raida bei nagrinejjamos kai kurių jos elementų taikymo ypatybės Lietuvos išsivadavimo judejime (1988-1991 m.). Po to analizuojama pilietinès gynybos bei pilietinio pasipriešinimo samprata Lietuvos saugumo ir gynybos politiką reglamentuojančiuose dokumentuose. Galiausiai mėginama atsakyti ị klausimą apie pilietinio pasipriešinimo vietą ir perspektyvas Lietuvos gynyboje.

\section{Pilietinès gynybos samprata}

Pilietinès gynybos idejai vystytis išsiskyrè dvi tradicijos: pacifistinè (principinè) ir pragmatine $\dot{e}^{19}$. Pirmoji traktuoja pilietinę gynybą kaip alternatyvą karinei, pabrèždama karinès ir pacifistinès strategijų nesuderinamumą. Pacifistinè gynybos samprata grindžiama moraliniais argumentais, joje prievarta, kaip konfliktų sprendimo būdas, nepateisinama jokiais, net ir kilniausiais tikslais. Antroji fizinès prievartos netaikymo reikalavimą grindžia pragmatiniais argumentais (socialiniais, politiniais, ekonominiais ir pan.): pilietiné gynyba taikoma ne todèl, kad ji moralesné už kitas

${ }^{16}$ Sharp G., Civilian-Based Defense: A Post-Military Weapons System Princeton: Princeton University Press, 1990; Anderson S., Larmore J., eds., Nonviolent Struggle and Social Defence, London: War Resisters International, 1991; Brian M., Social Defence, Social Change, London: Freedom Press, 1993; Ackerman P., Kruegler Ch., Strategic Nonviolent Conflict: The Dynamics of People Power in the Twentieth Century, Westport: Praeger Publishers, 1994; Burrowes R. J. The Strategy of Nonviolence Defense: A Gandhian Approach, Albany, NY: State University of New York Press, 1996;. Powers R. S., William B., eds., Protest, Power, and Change: An Encyclopedia of Nonviolent Action, New York: Garland Publishing, 1997; Ackerman P., Duvall J., A Force More Powerful: A Century of Non-Violent Conflict, New York: St. Martin's Press, 2000.

${ }^{17}$ Roberts A., Civil Resistance in the East European and Soviet Revolutions, Cambridge, MA: The Albert Einstein Institution, Monograph Series 4, 1991; Bleiker R., Nonviolent Struggle and the Revolution in East Germany, Cambridge, MA: The Albert Einstein Institution, Monograph Series 6, 1993; Eglitis O., Nonviolent Action in the Liberation of Latvia,Cambridge, MA: Albert Einstein Institution, 1993; Lieven A., The Baltic Revolution; Estonia, Latvia, Lithuania and the Path to Independence, New Haven and London: Yale University Press, 1993.

${ }^{18}$ Miniotaite G., Nonviolent Resistance in Lithuania: A Story of Peaceful Liberation. Monograph series 8 , Boston: Albert Einstein Institution, 2002.

${ }^{19}$ Apie principinę ir pragmatinę neprievartą žr.: Holms R., ed., Nonviolence in Theory and Practice, Belmont, California: Wadsworth Publishing Company, 1990, p. 1-6. 
gynybos formas, o todèl, kad, esant tam tikroms aplinkybėms, ji yra efektyvesnè už karinę. Pragmatinejje interpretacijoje pilietinè gynyba traktuojama kaip visuotinès gynybos sudedamoji dalis, kaip karinès gynybos papildymas.

Pilietinė gynyba kaip alternatyva karinei neegzistuoja jokioje pasaulio šalyje; pragmatiškai interpretuojamos pilietinės gynybos elementai įeina į kai kurių valstybių gynybos koncepcijas. Nenuostabu, kad pilietinès gynybos strategijos studijos daugiausiai vystomos pragmatinés tradicijos rèmuose. Kyla klausimas, kaip turètų būti kuriama analogo pasaulyje neturinti gynybos teorija. Matyt, šiuo atveju tenka kalbėti apie hipotetinės teorijos kūrimą, kurios empirinis pagrindas yra analizuoti įvykusius neginkluoto pasipriešinimo epizodus, ypač susijusius su pasipriešinimu okupacijai ir valstybės perversmams. Teoriniu naujos gynybos sampratos pagrindu tampa karinès strategijos klasikai-Carl von Clausewitz, Sun-Tzu bei šiuolaikinès karinès strategijos žinovų, tokių kaip Stephen KingHall ir Basil Liddell-Hart, mintys apie nemilitarinę gynybą ${ }^{20}$.

$\mathrm{XX}$ a. septintajame dešimtmetyje pasirodžiusiose pilietinès gynybos studijose pirmiausiai buvo mėginama suprasti neprievartinès kovos veiksmingumo, sprendžiant socialinius ir politinius konfliktus, prigimtį. Iš publikacijų, analizuojančių istorini neprievartinès rezistencijos patyrimą ${ }^{21}$, ypač išsiskyre išsami trijų tomų Gene Sharp studija The Politics of Nonviolent Action (1973) ${ }^{22}$. Šioje knygoje Sharp aprašè 198 neprievartinio veiksmo metodus bei suformulavo pagrindinius jo dinamikos principus. Neprievartinis veiksmas knygoje apibrèžiamas kaip ,,a technique used to control, combat and destroy the opponent's power by nonviolent means of wielding power" ${ }^{\text {“23 }}$. Sharp atsiriboja nuo prievartos sąvokos vartojimo plačiaja prasme, kai ji tapatinama su viskuo, kas slopina žmogaus fizinių ir dvasinių potencijų vystymąsi. Prievarta yra siejama tik su veiksmais bei elgesio formomis, grasinančiomis žmogaus gyvybei. Neprievartiné kova draudžia fizini smurtą, tačiau neatmeta kitokių spaudimo priešininkui formų ${ }^{24}$.

Neprievartinio veiksmo politika grindžiama tam tikra valdžios galios samprata. Sharp požiūriu, politinè valdžia išlaiko savo galią vidinių visuomenės šaltiniu dẻka: tai autoritetas, žmonių ištekliai, jụ igūdžiai ir žinios, dvasiniai veiksniai, materialiniai ištekliai ir sankcijos ${ }^{25}$. Šie šaltiniai gali efektyviai maitinti valdžią tol, kol piliečiai jai paklūsta ir su ja bendradarbiauja. Valdomieji, nutraukdami savo paramą

\footnotetext{
${ }^{20}$ King-Hall S., Defence in the Nuclear Age, London: Victor Gollancz, 1958. Šioje knygoje Stephen King-Hall rekomenduoja Didžiajai Britanijai atsisakyti atominès ginkluotès ir vystyti pilietinę gynybą.

Taip pat žr.: Liddell-Hart (note 6).

${ }^{21}$ Dažniausiai pateikiami pavyzdžiai yra Vokietijos kova prieš Belgijos ir Prancūzijos okupaciją 1923 m., Indijos kova dèl nepriklausomybės, neprievartinè rezistencija prieš nacių okupaciją Vakarų Europoje pasipriešinimas $1961 \mathrm{~m}$. Alžyro generolų maištui, 1968 metų Čekoslovakijos pasipriešinimas Sovietụ invazijai, Marcos diktatūros Filipinuose žlugimas 1986 metais, palestiniečių kova 1987-1993 m., komunistinių režimų žlugimas Rytų Centrinejje Europoje 1989 metais.

${ }^{22}$ Sharp, G., The Politics of Nonviolent Action, Boston:Porter Sargent Publishers, 1973. Amerikiečių profesoriaus Gene Sharp darbai susilaukẻ plataus tarptautinio pripažinimo, jie yra išversti i daugiau negu 30 kalbụ, taip pat ị lietuvių, estụ, latvių, rusų.

${ }^{23}$ „Neprievartinis veiksmas yra technika, naudojama kontroliuoti, kovoti ir sužlugdyti oponento galią neprievartinèmis priemonėmis“, Sharp (note 22), part I p. 4.

${ }^{24}$ Lazari-Pawlowska I, „Ethical Aspects of Resistance“, The Modern Churchman 2 (30),1988, p.

$7-14$.

${ }^{25}$ Sharpas. G., Pilietine gynyba: postmilitariniu ginklu sistema, Vilnius: Mintis, 1992, p. 28-29.
} 
valdžiai, gali neprievartinèmis priemonėmis ją kontroliuoti ir net sužlugdyti. „If they do this in sufficient numbers for long enough, that government or hierarchical system will no longer have power. This is the basic political assumption of nonviolent ac-

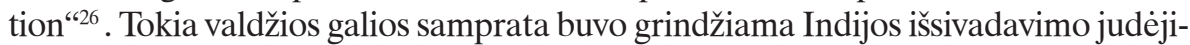
mo lyderio M. Gandhi veikla. 1920 m. jis rašè , „[...] no government can exist for a single moment without the cooperation of the people, willing or forced, and if people suddenly withdraw their cooperation in every detail, the government will come to a standstill“272 . Vèliau tą pačią mintị pakartojo Hannah Arendt: „the people lend their power and support to the government by agreeing to act according to its rules" ${ }^{\prime 28}$. Kenneth Boulding ją vadina integrativi galia (ang. integrative power) ${ }^{29}$.

Sharp apibréžia pilietinę gynybą kaip ,pačių piliečių, o ne karinio personalo vykdomą gynybą, naudojantis pilietinėmis, o ne karinėmis ar pusiau karinėmis kovos priemonemis “30. Tai , a projected refinement of the general technique of nonviolent action“, ,„[...] an attempt deliberately to adapt and develop that technique to meet defend needs ${ }^{\text {‘31 }}$. Pilietinès gynybos teoretiko Robert Burrowes požiūriu, strateginis pilietinès gynybos tikslas yra „, to consolidate the power and will of the defending population to resist the aggression“, , ,[...] to alter the will of the opponent elite to conduct the aggression, and to undermine their power to do so"32. Siame procese susipina du tikslai: priešininko atgrasymas (oponento valios pakeitimas) ir gynyba. Jei oponentas nekeičia valios, ji galima priversti tai padaryti neprievartiniais veiksmais, kurie pilietinejje gynyboje atlieka ginklų vaidmenį.

Neprievartinès kovos ginklai skirstomi i tris dideles kategorijas: 1) neprievartinis protestas ir įtikinimas (demonstracijos, piketai, protesto mitingai, viešos paskaitos ir diskusijos ir t. t.); 2) nebendradarbiavimas: „Veiksmai, kuriais nutraukia$\mathrm{mi}$, apribojami ar ignoruojami tam tikri santykiai - socialiniai, ekonominiai arba politiniai““33 (streikai, boikotai, mokesčių nemokẻjimas, rinkimų ir teisètvarkos boikotas, pilietinis nepaklusnumas); 3) neprievartinis įsikišimas: „Disruption or destruction of behavioral patterns, policies, relationships, or institutions that are consi-

\footnotetext{
${ }^{26}$ „Jei jie tai daro pakankamai daug kartų ir pakankamai ilgą laiką, vyriausybe arba hierarchinė sistema netenka galios. Tai yra pagrindine neprievartinio veiksmo politikos prielaida“. Sharp, (note 22 ) p. 64.

${ }^{27},[\ldots]$ jokia vyriausybė né minutės negali egzistuoti be žmonių bendradarbiavimo su ja, savanoriško ar priverstinio. Jei žmonès staiga visiškai nutrauks bendradarbiavimą, vyriausybė pateks į aklavietę". Cituojama pagal Sharp, (note 11) p. 44.

${ }^{28}$ „Žmonés paskolina savo galią ir paramą vyriausybei sutikdami elgtis pagal jos taisykles“. Cituojama pagal: Presbey G. M., „Hannah Arendt on nonviolence and political action“ in Kool V. K., eds., Nonviolence: Social and Psychological Issues. Lanham: University Press of America, 1993, p. 249. ${ }^{29}$ Boulding K. E., „Peace, Justice, and the Faces of Power“ in Wehr P., H. Burgess and G. Burgess, eds., Justice without Violence, Boulder: Lynne Rienner Publishers, 1994, p. 51.

${ }^{30}$ Sharp, (note 25) p. 12.

${ }^{31}$ Tai - ,,apgalvotas bendros neprievartinio veiksmo technikos patobulinimas $[\ldots]$ “, ,,méginimas ją pritaikyti ir išvystyti gynybos poreikiams“. Sharp G., Social Power and Political Freedom, Boston, Mas.: Porter Sargent Publishers, 1980, p. 233.

32 „Konsoliduoti pasipriešinimui prieš agresiją gynyboje dalyvaujančių gyventojų galią ir valią“; „pakeisti oponento elito valią tęsti agresiją bei pakirsti jo galią tai daryti“. Burrowes, (note 16) p. 209.

${ }^{33}$ Sharp, (note 25) p. 43.
} 
dered unacceptable“34 (neprievartinè blokada ir okupacija, badavimas, ikalinimo siekimas, alternatyvių politinių, ekonominių, socialinių institucijų steigimas, alternatyvios mokyklos, paralelinis transporto, komunikacijų tinklas).

Pilietinè gynyba reikalauja ypatingo gyventojų pasiruošimo bei jos lyderių strateginio kūrybingumo. Neginkluota gynyba prieš ginkluotą priešininką reikalauja visuomenès vieningumo, išvystytos pilietinès visuomenès, asmeninės dalyvių drąsos, neprievartinès disciplinos (neatsakyti smurtu ị represijas), sugebẻjimo atskleisti ir išnaudoti priešininko silpnąsias puses. Be to, tai ypatingas santykis su priešininku: pilietinèje gynyboje nesiekiama nužmoginti priešininko - tikslas yra neutralizuoti jo priešiškumą ir, jei pavyks, paversti jį sajungininku.

Iš šios trumpos pilietinės gynybos teorijos apžvalgos gali susidaryti įspūdis, kad pilietinès gynybos teoretikai kuria utopinio pasaulio utopinę teoriją. Kaip rodo istorija, taikių permainų laikotarpius keičia nauji smurto protrūkiai, vedantys ne prie neprievartinio veiksmo, o prie karinès ginkluotès tobulinimo. Kiek realus yra pilietinès gynybos igyvendinimas? Pirmiausiai reikètų neužmiršti, kad karinès gynybos istorija siekia tūkstantmečius, valstybingumo išsaugojimo pagrindimas yra konceptualizuojamas karinès galios kategorijomis. Tuo tarpu pilietinės gynybos ideja gyvuoja viso labo kelis dešimtmečius. Pilietinès gynybos teoretikai, ypač pragmatinès orientacijos, žengia dar tik pirmuosius idejjos pagrindimo žingsnius. Jų požiūriu, perèjimas nuo teorijos prie jos praktinio igyvendinimo turètų prasidèti iš viršaus, t. y. ịvedant kai kuriuos pilietinès gynybos elementus ị nacionalinès gynybos sistemą. Tokio proceso tikslingumui devintajame XX amžiaus dešimtmetyje pritare ir kai kurių Europos valstybių valdžios atstovai. $1986 \mathrm{~m}$. Švedijos Parlamentas pritare Nemilitarinès rezistencijos komisijos įsteigimui. $1990 \mathrm{~m}$. Norvegijos gynybos ministras Johan Holst pažymejo: „Civilian-based defence has the potential of constituting an important complement to traditional military forms of resis-

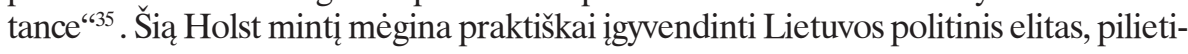
niam pasipriešinimui Lietuvos gynyboje skirdamas svarbią vietą.

\section{Neprievartinis veiksmas ir pilietinè gynyba Lietuvos išsivadavimo judèjime: 1988-1991 m.}

Daugelyje SSSR žlugimui nušviesti skirtų publikacijų pažymima, kad Sovietų imperijai subyrant Lietuva atliko katalizatoriaus vaidmenį. Imperijos žlugimas yra sudètingas, įvairiapusis procesas, veikiamas daugybès vidaus ir išorès faktorių. Daugelis autorių, analizuojančių Sovietų imperijos žlugimą, atkreipé dėmesị i jo taikų pobūdį $i^{36}$, tačiau išsami šio proceso analizè neprievartinio veiksmo teorijos požiūriu dar laukia savo tyrinètojų. Lietuvoje platus neprievartinio veiksmo taikymas 1988-

${ }^{34}$, Žlugdymas arba destrukcija tokių elgesio modelių, politikos, santykių ar institucijų, . kurie laikomi nepriimtinais“. Burrowes R., The Strategy of nonviolent defence, http://polar.alaskapacific.edu/gregb/sc430n5.html, 20082003.

${ }^{35}$ „Pilietinè gynyba turi galimybę tapti svarbiu tradicinių karinių pasipriešinimo formu papildymu“, Holst J. J., Civilian-Based Defence in a New Era, Cambridge, Mass.: Albert Einstein Institution, Monograph Series No 2, 1990, p. 14-15.

${ }^{36}$ Lieven A., The Baltic Revolution: Estonia, Latvia, Lithuania and the Path to Independence, New Haven and London: Yale University Press, 1993; Smith G., eds., Baltic States: National SelfDetermination of Estonia, Latvia and Lithuania , London: Macmillan, 1994; Gerner K., Hedlund S., Baltic States and the End of the Soviet Empire, London: Routledge, 1993. 
1991 m. suvaidino svarbų vaidmenị kovojant dèl nepriklausomybès. Šị laikotarpị tikslinga suskirstyti ị du periodus: pirmasis - nuo Sajūdžio ịsisteigimo iki nepriklausomybės deklaravimo $1990 \mathrm{~m}$. kovo $11 \mathrm{~d}$; antrasis periodas baigiasi Lietuvos prièmimu į JT organizaciją $1991 \mathrm{~m}$. rugsèjo 17 d. Pirmajam periodui būdingas spontaniškas neprievartinio veiksmo metodų taikymas kovojant dẻl valstybès suvereniteto prieš Vilniaus ir Maskvos nomenklatūrą, antrajame vyksta kova prieš Sovietų Sajungos karinę ir politinę nomenklatūrą dèl paskelbtos nepriklausomybẻs išsaugojimo ir įtvirtinimo. Šiuo periodu ginant valstybingumą atsiranda apgalvoto ir organizuoto neprievartinio veiksmo technikos taikymo elementu, t. y. pilietinės gynybos užuomazgų.

\section{Pilietinès gynybos elementai kovojant dèl Lietuvos nepriklausomybès išsaugojimo: 1990-1991 m.}

Lietuva buvo pirmoji Sovietų Sajungos respublika, vienašališkai paskelbusi valstybės nepriklausomybę. $1,5 \%$ beginklių gyventojų, užimančių $0,3 \%$ teritorijos, kurioje tuo metu buvo dislokuota Sovietų kariuomenè, metẻ iššñkị didžiulei, turinčiai galingą represinį aparatą imperijai. Po kelių dienų neeilinis SSSR deputatų suvažiavimas paskelbė Lietuvos nepriklausomybės deklaraciją neturinčia juridinės galios ir pareikalavo „atkurti tvarką ir teisètumą" Lietuvos teritorijoje. Žvelgiant iš SSSR pozicijų, visi tolimesni Lietuvos veiksmai atkuriant valstybingumą yra neteisèti, neprievartinio veiksmo teorijos požiūriu jie gali būti ịvardinti kaip pilietinis nepaklusnumas. Tuo tarpu Žvelgiant iš Lietuvos pozicijų - tai valstybingumo gynimas ir įtvirtinimas. Atsakomajame laiške suvažiavimui Vytautas Landsbergis pabrěžè, kad užsienio valstybės rezoliucijos neturi juridinès galios Lietuvoje ir kad teisèti SSSR interesai galètų tapti derybų objektu. Abi pusės jautėsi esančios teisios ir nuosekliai siekẻ realizuoti savo tikslus. Esminis skirtumas buvo tas, kad Lietuvos valdžia rèmėsi visuotine žmonių parama, tuo tarpu SSSR vadovybė galèjo kliautis tik represinėmis struktūromis.

Po nepriklausomybès paskelbimo SSSR santykiuose su Lietuva vyravo ultimatyvus tonas: grasinimai sugriauti ekonomiką, atimti kai kurias teritorijas, supriešinti visuomenę. Lietuvos valdžia siūle pradèti derybas ir, nepaisydama grasinimų, kūré institucijas, îtvirtinančias valstybės suverenitetą. Buvo priimtas Respublikos piliečio pažymėjimo įstatymas, pradètas valstybės sienų žymëjimas ir kontrolè, įsteigtas Lietuvos Krašto apsaugos departamentas. Maskva į šiuos veiksmus atsake ekonomine blokada, pastatų okupavimu ir niokojimu, karinę tarnybą boikotuojančiu jaunuolių gaudymu. $2991 \mathrm{~m}$. sausio mèn. buvo pamėginta su desantininkų ir tankų pagalba susigrąžinti Lietuvos paklusnumą. Nors buvo brutaliai užimti Spaudos rūmai, Radijo ir televizijos pastatas, televizijos transliacijos bokštas, tačiau SSSR Prezidento Michail Gorbačiov telegramoje Lietuvos AT suformuluotas tikslas - „tučtuojau visiškai atkurti TSRS konstitucijos ir Lietuvos SSSR konstitucijos galiojimą, atšaukti priimtus konstitucinius

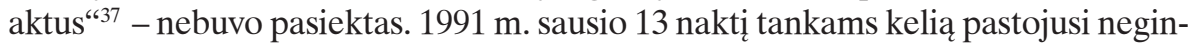
kluotųžmonių minia sužlugdè karinio perversmo ịgyvendinimąa $a^{38}$.

${ }^{37}$ Lietuva, 1991.01.13: Dokumentine medžiaga, Vilnius: Valstybinis leidybos centras, 1991, p. 23.

${ }^{38}$ Tą naktị gindami televizijos bokštą žuvo 13 Lietuvos gyventojų, 702 buvo sužeisti. Ten pat, p. 360 . 
Lietuvos AT, mesdama iššūkị imperijai, iš pat pradžiu orientavosi į netradicines, neginkluotos kovos formas, daugiausiai $i$ jau išmėgintus neprievartinio veiksmo metodus. Didejjant ginkluotos agresijos pavojui, stiprejo suvokimas, kad atsvara jai gali būti tik vadinamas Gandžio kelias. 1990 m. gruodžio mèn. bendroje AT Sajūdžio remiamų deputatų, savivaldybių deputatų atstovų tarybos ir Sajūdžio Seimo konferencijoje buvo paskelbtas kreipimasis „Respublika pavojuje“. Jame visi Lietuvos žmonés buvo kviečiami „laikytis nepaklusnumo ir nebendradarbiavimo su okupaciniais organais principu “"39. $1991 \mathrm{~m}$. sausio 8 d., kai Maskvos agresija atrodė neišvengiama, Landsbergis per radiją kreipèsi į Lietuvos žmones: „Ateikite ir paremkite savo valdžią, kitaip galite turèti svetimą “40 . Per televiziją buvo parodytas Richard Attenborough filmas „Gandhi“. Prasidejo nuolatinis Sajūdžio organizuotas Lietuvos gyventojų budëjimas prie Seimo, Spaudos rūmų, televizijos transliacijos bokšto. Kartu su civiliais gyventojais budejjo neginkluoti policininkai, Policijos akademijos studentai. Jų pagrindinis uždavinys buvo užkirsti kelią ginkluotoms provokacijoms.

Sausio ịvykiai Lietuvoje ir Latvijoje ${ }^{41}$ nepateisino Maskvos lūkesčių. Toliau dirbo Lietuvos Aukčíiausioji ir Ministrų tarybos, savivaldybės kontroliavo padètį miestuose. Policija liko ištikima Lietuvos respublikai. Be to, labai išaugo valdžios autoritetas ir žmoniu parama jai. Prievartos naudojimas prieš taikius gyventojus atvedè prie vadinamo politinio džiu-džitso: tai tokia situacija, kai dèl prievartos naudojimo padidẻja rezistentų skaičius ir gyventojų nepaklusnumas, ǐšryškèja nesutarimai tarp priešininkų, sumažẻja jų galimybès palaužti nepaklusnumą ir tęsti savo politiką . Britų žurnalistas Anatol Lieven pastebi: „Soviet measures however only increased the determination and morale of ordinary Lithuanians. Those who, immediately after declaration [of independence], had been critical of Landsbergis and Sajudis, became increasingly supportive, and popular demonstrations returned to their preindependence dimensions ${ }^{443}$. Be to, del Sausio įvykių labai išaugo Sovietų Sajungos gyventojų bei kitų šalių parama Lietuvos nepriklausomybei. Sausio įvykiai Lietuvoje akivaizdžiai parode neginkluotos gynybos efektyvumą: civiliai gyventojai apgynẻ labai svarbius Lietuvos nepriklausomybei objektus - Aukščiausiają Tarybą, Televizijos stotį Sitkūnuose, leidusią atnaujinti TV transliaciją. Tad neatsitiktinai po Sausio ịvykių sustiprèjo ir Lietuvos vyriausybès bei visuomenès orientacija ị pilietinę gynybą. Ji buvo suprantama kaip iš anksto organizuotas žmonių galios panaudojimas valstybės gynimo tikslams. Antai 1991 m. vasario 28 d. AT paskelbtoje rezoliucijoje teigiama:

Prasidèjus atvirai okupacijai, stodami ị kovą už nepriklausomybę, Lietuvos respublikos piliečiai kviečiami laikytis neklusnumo, nesmurtinio pasipriešinimo ir politinio bei socialinio nebendradarbiavimo principų ${ }^{44}$.

${ }^{39}$ Landsbergis V., Laisves byla, Vilnius: Lietuvos Aidas, 1992, p. 182.

${ }^{40}$ Ten pat, p. 186.

${ }^{41}$ Eglitis O., Nonviolent Action in the Liberation of Latvia, Cambridge, MA: Albert Einstein Institution, 1993, p. 31-35.

${ }^{42}$ Apie politinio džiu-džitso sąvoką žr. Sharp (note 25) p. 57-59.

${ }^{43}$ „Sovietų naudojamos priemonès „sustiprino paprastų lietuvių apsisprendimą ir dvasią. Ypatingai sustiprèjo parama tu žmonių, kurie iš karto po nepriklausomybès deklaracijos paskelbimo kritikavo Landsbergị ir Sajūdị; protesto demonstracijos igavo ankstesnị mastą“. Lieven, (note 36) p. 239. Tai patvirtino ir $1991 \mathrm{~m}$. sausio 14 diena Vilniaus universiteto sociologijos laboratorijos ir Lietuvos mokslų akademijos Viešosios nuomonès tyrimų centro atlikta apklausa, kuri parodè, kad po Sausio i̇vykių labai išaugo netgi Lietuvoje gyvenančių kitataučių, ypač rusų, pritarimas Lietuvos nepriklausomybei. Žr. Lietuvos Aidas, 19910123.

${ }^{44}$ Lietuvos Respublikos Aukščiausios tarybos ir vyriausybès žinios, 1991, t. 8, p. 324. 
Tokiai rezoliucijai atsirasti įtakos turejjo ne tik sukauptas praktinis patyrimas, bet ir pažintis su teorinèmis pilietinès gynybos studijomis. ${ }^{45}$ Pirmiausiai buvo mėginama pritaikyti kai kuriuos pilietinės gynybos elementus Sovietų agresijos atgrasymo tikslams. Buvo siekiama ịtikinti Sovietų politinị ir karinị elitą, kad jų tikslas - jèga susigrąžinti Lietuvą - yra nepasiekiamas, o méginimas tai daryti atneštu didžiulę materialinę ir moralinę žalą perestroikai ir tarptautiniam šalies prestižui. Jau sausio mėnesį Krašto apsaugos departamentas pradėjo leisti laikraštic rusų kalba Doroga Litvy (Lietuvos kelias). Laikraštis buvo platinamas tarp sovietų kariškių, tarnavusių Lietuvoje bei Sovietų Sajungoje. Taip pat buvo tiražuojama ir platinama medžiaga apie Sausio įvykius. Sajūdis, AT deputatai, vyriausybè bei paprasti Lietuvos gyventojai palaikè glaudžius ryšius su nacionalinio išsivadavimo judèjimais visoje Sovietų Sajungoje, mėgindami daryti įtaką demokratizacijos procesų eigai ${ }^{46}$.

Rengiantis pilietinei gynybai svarbus uždavinys buvo gyventojų ir kariškių švietimas, jų nuteikimas naudotis pilietinès gynybos ginklais. „Tai netradicinė ginklų sistema, kurią valdyti reikia mokytis. Ji reikalauja daug daugiau žinių, intelekto, žmogiškosios prigimties supratimo nei ịprastinis šautuvas ar policininko lazda“, - rašė Krašto apsaugos ministras Audrius Butkevičius G. Sharp knygos publikacijos lietuvių kalba proga ${ }^{47} .1991 \mathrm{~m}$. vasario mèn. vyriausybès įsakymu buvo įsteigta Psichologinès gynybos ir pilietinio pasipriešinimo komisija. İsakyme numatoma ,parengti pilietinio pasipriešinimo instrukciją, skirtą KAD etatiniams darbuotojams ir SKA savanoriams, [...] organizuoti savanorių mokymą pagal neprievartinio pasipriešinimo programas ${ }^{\text {‘48 }}$. Savanoriška krašto apsaugos tarnyba daug dėmesio skyrė savanorių mokymams organizuoti, rèmè reikiamos literatūros vertimą li lietuvių kalbą ${ }^{49}$. Siekdami padèti gyventojų švietimui, pagrindiniai Lietuvos laikraščiai spausdino medžiagą, skirtą pilietinės rezistencijos istorijai, jos metodų analizei. Taip pat buvo organizuotos televizijos laidos, supažindinančios gyventojus su pagrindiniais pilietinės gynybos principais. $1991 \mathrm{~m}$. rugpjūčio 19 d. prasidejjus pučui Maskvoje, V. Landsbergis pakartojo, kad ,pagrindinis Lietuvos pasipriešinimas okupacijos atveju yra neginkluotas, nesmurtinis pasipriešinimas ${ }^{“ 50}$. Lietuvos žmonès vèl buvo pakviesti rinktis prie AT pastato. Krašto apsaugos departamentas išleido įsakymą, kuriuo krašto apsaugos sistemos darbuotojai okupacijos atveju įpareigojami „organizuoti ir vykdyti pilietinio pasipriešinimo akcijas visoje Lietuvos respublikos teritorijoje, naudojant nesmurtinio pasipriešinimo metodiką “"51 .

${ }^{45}$ Jau 1990 metu pabaigoje Sharp knyga Civilian-Based Defence (1990) buvo išverstos ị lietuviu kalbą. Vertimo rankraštis buvo ịdemiai studijuojamas Krašto apsaugos departamento direktoriaus, kitụ pareigūnų, Sajūdžio aktyvistų. Taip pat buvo išversta ir 1992 metais publikuota Sharp knyga Self-Reliant Defense without Bankruptcy or War (1990).

${ }^{46}$ Prasidejus Donecko ir Kuznecko sričiu šachtininku streikams, Darbininku Sajungos iniciatyva Lietuvoje buvo renkami maisto produktai streikuojantiems. Paramos gabenimas sunkvežimiais per Sovietų Sajungą turejjo didžiulę idejjinę reikšmę; kartu su maisto produktais keliavo ir pozityvi informacija apie Lietuvą.

${ }^{47}$ Sharpas, (note 25 ) p. 147.

${ }^{48}$ Krašto apsaugos departamento ìsakymas Nr.12, $1991 \mathrm{~m}$. vasario 20 d. (Autorés archyvas).

${ }^{49}$ Buvo išversti ištisi skyriai iš knygu, straipsniai apie Suomijos, Indijos, Norvegijos, Filipinu, Lenkijos Solidarumo neprievartinés kovos patyrimą. Savanorio bibliotekéleje buvo išspausdintas Sharp straipsnis „Jègos vaidmuo nesmurtineje kovoje“ (The role of power in nonviolent struggle). Savanorio bibliotekèle 3, 1991.

${ }^{50}$ Landsbergis, (note 39) p. 284.

${ }^{51}$ Krašto apsaugos departamento ìsakymas Nr. 160., 1991 m. rugpjūčio 18 d. (Autorès archyvas). 
Netrukus po rugpjūčio pučo Maskvoje pralaimèjimo Lietuva sulaukẻ tarptautinio pripažinimo - $1991 \mathrm{~m}$. rugsèjo $17 \mathrm{~d}$. ji tapo JT nare.

Trumpa Lietuvos kovos dèl nepriklausomybės 1988-1991 m. apžvalga patvirtina neprievartinio pasipriešinimo efektyvumą bei atskleidžia jo perspektyvas valstybẻs gynyboje. Tačiau būtų naivu pasiektą rezultatą aiškinti tik neprievartinio pasipriešinimo strategija. Lietuvos Nepriklausomybės deklaracija buvo priimta esant ypač palankioms vidaus ir išorés aplinkybėms. Perestroika, Sovietų Sajungoje atvėrusi kelius viešumui ir demokratizacijai, išjudino totalitarinio režimo pagrindus. Tuo pačiu metu „Solidarumo“ pergalé Lenkijoje, vadinama aksominè Čekoslovakijos revoliucija, Vokietijos susivienijimas sukūre pabrěžtinai palankų tarptautinị klimatą išsivadavimo judejimams Baltijos valstybėse. Lietuvoje, kaip ir kitose Baltijos valstybėse, per kelis metus buvo sukauptas vertingas pilietinio pasipriešinimo patyrimas, susiformavo nepriklausomos struktūros, kurios suteikè jam kryptị ir idèjinị pagrindimą. Po Nepriklausomybes deklaracijos paskelbimo susidarė unikali situacija, kai sutapo naujai besiformuojančių valdžios struktūrų ir visuomenès tikslai. Be to, gyventoju sugebèjimas išsaugoti neprievartinę discipliną, nepasiduodant priešininko provokacijoms į smurtą atsakyti smurtu, padejo Lietuvai laimèti pasaulio viešosios nuomonés paramą. Nepriklausomybẻ buvo pasiekta su minimaliomis žmonių aukomis, išsaugant šalies resursus bei infrastruktūrą.

\section{Pilietinis pasipriešinimas Lietuvos saugumo ir gynybos sistemoje}

Po tarptautinio Nepriklausomybès pripažinimo Lietuvoje pradėjo formuotis savarankiška vidaus ir užsienio politika, kuri orientavosi į mažos valstybės teoriją: „A small state's foreign policy must first of all deal with the potential threat posted by great powers in order to secure its own survival " ${ }^{\text {"52 }}$. Matydama pagrindinę grèsmę nestabilioje ir neprognozuojamoje Rusijoje, Lietuva palaipsniui atsisakè tilto tarp Rytų ir Vakarų įvaizdžio ir ryžtingai pasuko suartėjimo su Vakarais linkme. Ši tendencija ypač sustiprejjo po Rusijos kariuomenès išvedimo iš Lietuvos 1993 m. Nuoseklus Vakarų krypties politikos ịgyvendinimas lėmé Lietuvos narystę NATO ir Europos Sajungoje (2004). Kyla klausimas, kaip atsispindi šiuolaikinès Lietuvos saugumo ir gynybos sistemoje neprievartinio pasipriešinimo patyrimas, suvaidinęs be galo reikšmingą vaidmenį siekiant nepriklausomybès pripažinimo. İ šį klausimą bus atsakyta apžvelgiant Lietuvos Saugumo ir Gynybos politikos konceptualizavimo ypatybes.

Nuo pirmųjų Lietuvos nepriklausomybės deklaravimo dienų valstybės ir tautos saugumas yra pagrindine Lietuvos politinio diskurso tema. Jau 1992 m. Krašto apsaugos ministerijos iniciatyva parengiamas pirmasis Nacionalinio saugumo koncepcijos projektas, kuriame gana reikšmingas vaidmuo skiriamas pilietinei gyny-

${ }^{52}$ „Mažos valstybės užsienio politika pirmiausiai privalo būti orientuota ị didelių valstybių keliamą grèsmę ir savo pačios išlikimą“. Knudsen O. F., „Baltic States’ Foreign Policies“, Nordic Journal of International Studies 1 (28), 1993, p. 48.

${ }^{53}$ „Lietuvos respublikos nacionalinio saugumo koncepcija. Projektas“ (1992), Žr.: Bagdonavičius V., sudar., Lietuvos nacionalinis saugumas: teorija ir realijos, Vilnius: Filosofijos, sociologijos ir teisès institutas, 1994, p. 125-145. 
bai $^{53}$. Tais pačiais metais Krašto apsaugos departamentas kartu su Alberto Einšteino institutu (JAV) surengè tarptautinę konferenciją apie pilietinès gynybos pritaikymą ir perspektyvas Baltijos valstybèse. Prie Civilinès saugos departamento ịsteigiamas Neprievartinès rezistencijos kabinetas, kuriame kaupiama medžiaga apie pilietini pasipriešinimą Lietuvoje ir kitose šalyse. Kabineto veiklą tęsė Pilietinio pasipriešinimo mokymo skyrius ${ }^{54}$ : jame krašto apsaugos ministerijos ir kitų institucijų pareigūnams buvo skaitomas trumpas pilietinio pasipriešinimo pagrindų kursas ${ }^{55}$. 1994 1995 m. buvo parengtas susitarimo projektas dèl Lietuvos, Latvijos ir Estijos pilietinès gynybos bendradarbiavimo. Nors visos šalys pritare susitarimo idejai, tačiau jis taip ir nebuvo pasirašytas. Artėjant narystei NATO, blèso dėmesys pilietinei gynybai, ypač Latvijoje ir Estijoje.

1996 m. pab. Seimo patvirtinti Lietuvos Nacionalinio saugumo pagrindai (NSP) suteike pilietiniam pasipriešinimui tvirtą teisinị pagrindą. Pilietinè gynyba dokumente apibrèžiama kaip esminè pilietinio pasipriešinimo dalis. Dokumento skyriuje Pilietinis pasipriešinimas (7.4) teigiama:

Lietuvos gynybos sistemos pagrindas - visuotinès ir besąlyginès gynybos principas. Pilietinio pasipriešinimo jègą lemia Tautos valia ir apsisprendimas kovoti už savo laisvę, kiekvieno piliečio, nesvarbu, koks jo amžius ir profesija, pasiryžimas visais įmanomais būdais priešintis užpuolikui ar okupantui, prisidèti prie Lietuvos gynybos. Piliečių pasirengimo pilietiniam pasipriešinimui sistema yra valstybinè. Jos funkcionavimą organizuoja Vyriausybè.

Užpuolimo, pasikèsinimo į Lietuvos teritorijos vientisumą arba jos konstitucinę santvarką atveju piliečiai ir jų savaveiksmiai dariniai imasi pilietinio pasipriešinimo veiksmų - nesmurtinio pasipriešinimo, nepaklusnumo ir nekolaboravimo su neteisèta administracija, taip pat ginkluoto pasipriešinimo ${ }^{56}$.

Pilietinio pasipriešinimo nuostatos taip pat įtvirtintos Lietuvos Nacionalinio saugumo (NSS, 2002) ir Nacionalines gynybos (2000) strategijose ${ }^{57}$. Vykdant Nacionalinio saugumo pagrindų įstatymą $2000 \mathrm{~m}$. Vyriausybės nutarimu ịsteigtas Valstybinis pilietinio pasipriešinimo rengimo centras prie Krašto apsaugos ministerijos. Jo paskirtis - , ,igyvendinti valstybės politiką rengiant visuomenę individualiam ir organizuotam pilietiniam pasipriešinimui““58 $2001 \mathrm{~m}$. pradèjęs veiklą, centras tęsia pilietinio pasipriešinimo skyriaus pradètus darbus.

Apžvelgus pilietinio pasipriešinimo idejjos ịgyvendinimą nepriklausomos Lietuvos laikotarpiu, galima teigti, kad kai kurie pilietinès gynybos elementai užima gana

\footnotetext{
${ }^{54}$ Skyrius buvo įsteigtas 1999 metais Generolo Adolfo Ramanausko kariu profesinio tobulinimosi centre.

${ }^{55}$ Mokymo pradžioje kurso klausytojai buvo Rezervo karių asociacijos nariai, Skautų sajungos vadovai, Šaulių sąjungos rinktinių vadai, karinių dalinių ryšių su visuomene specialistai ir karių ramovių darbuotojai. Žr.: Mankevičius V., Daugirdas A., Pilietinis pasipriě̌inimas, Vilnius: Mažoji Evelina, 2002, p. 3.

56 „Lietuvos respublikos nacionalinio saugumo pagrindu ịstatymas“, Valstybès žinios 2, 1997, p. 2-20. ${ }^{57}$ Nacionalinio saugumo strategija, $2002 \mathrm{http}: / /$ www.kam.lt/catalog/ministerija/nacionalinio_saugumo_strategija_06_05.doc;

Nacionalinès gynybos strategija, 2000, http://www.kam.is.lt/index.php?ItemId=9675 20030314 .

${ }^{58}$ Nutarimas dèl Valstybinio pilietinio pasipriešinimo rengimo centro prie Krašto apsaugos ministerijos įsteigimo 1359, 200011 07, Valstybès žinios 98, 2000, p. 73.
} 
svarbią vietą pagrindiniuose Lietuvos saugumo ir gynybos politiką apibrèžiančiuose dokumentuose. „Visuotinis piliečiu pasirengimas pasipriešinimui“ laikomas svarbia potencialaus užpuoliko atgrasymo proceso dalimi. Tačiau šis pasirengimas šviečiant gyventojus nėra visuotinio pobūdžio, jis daugiausiai yra skirtas su Krašto apsaugos ministerija susijusioms institucijoms. Sprendžiant pagal programą, Pilietinio pasipriešinimo rengimo centro veikla turètų apimti platesnius gyventojų sluoksnius: joje numatomas glaudus bendradarbiavimas su mokymo ir mokslo įstaigomis, bažnyčia, valstybès, vietos savivaldos institucijomis ir visuomeninėmis organizacijomis.

Pilietiniam pasipriešinimui skiriama svarbi vieta ne tik siekiant atgrasyti nuo agresijos, bet ir sprendžiant gynybos klausimus. Lietuvos visuotinès ir besąlyginès gynybos modelis labiausiai primena aštuntojo dešimtmečio Šveicarijos totalinès gynybos (vok. Gesamptverteidigung) strateginę triadą, kurią sudaro karinè gynyba, partizaninis karas ir nekarinè gynyba ${ }^{59}$. Kaip rašoma Nacionalinio saugumo pagrinduose, Lietuva priešinsis agresoriui karine gynyba ir pilietiniu pasipriešinimu, t. y. partizanine kova bei nesmurtinio pasipriešinimo veiksmais. Pilietinis pasipriešinimas turètų prasidėti nutraukus karinę gynybą ir agresoriui okupavus šali. Šioje gynybos stadijoje iškyla esminis pilietinio pasipriešinimo strategijos klausimas: ar suderinama ginkluotas partizaninis karas ir neginkluota pilietinè gynyba? Pilietinès gynybos teoretikai gana vienareikšmiškai tvirtina, kad gynyba, kurioje ginkluota kova taikoma kartu su neprievartiniu pasipriešinimu, yra pasmerkta nesèkmei. Esant tokiai gynybos taktikai pakertamos pilietinio pasipriešinimo efektyvumo šaknys - moralinis rezistentų pranašumas, kuris yra labai svarbus siekiant palankios tarptautinès reakcijos. Be to, ginkluotą kovą lydintis smurtas, atsitiktinès civilių aukos, gyvenamos aplinkos niokojimas suteikia priešininkui pagrindą pateisinti represijas ${ }^{60}$.

Nekelia abejonių, kad tolimesnis pilietinio pasipriešinimo bei pilietinès gynybos idejjų plètojimas reikalauja jų išsamesnio teorinio pagrindimo, santykio tarp ginkluotos ir neginkluotos gynybos strategijų analizès, socialinių ir politinių prielaidų, būtinų šiai netradicinei gynybos formai igyvendinti, studijų ${ }^{61}$.

Pilietinio pasipriešinimo ịtraukimas ị Lietuvos saugumo ir gynybos sistemą pagrịstas visuotinès ir besąlyginės gynybos principu, reikalaujančiu „visus ir kiekvieną pilietị priešintis agresoriui visomis įmanomomis priemonèmis“" (NSS, 6.3.4). Atsakymas ị klausimą, ar laiku rodomas dėmesys pilietiniam pasipriešinimui Lietuvos saugumo sistemoje, slypi atsakyme į klausimą, ar nepavèluotas yra visuotinès ir besąlyginès gynybos principas. Lietuvos politinio elito orientaciją į visuotinę ir besąlyginę gynybą lèmé ịvairūs faktoriai, iš kurių pirmiausiai išskirtina specifinè tarpukario Lietuvos istorijos interpretacija. Tai tarsi skausminga dabarties polemika su $1940 \mathrm{~m}$. ịvykiais, kai militarizuota Lietuvos valstybė jokia forma nepasipriešino Sovietų Są-

${ }^{59}$ Низинг, (note 9) p. 29.

${ }^{60}$ Низинг, (note 9); Sharp (note 25); Ackerman (note 16). Tą pačią mintį išreiške buvęs Lietuvos Krašto apsaugos ministras Audrius Butkevičius: „Kai valstybė pereina prie pilietinės gynybos pobūdžio pasipriešinimo, tuos, kurie organizuoja tolimesnị pasipriešinimą naudodami smurtą, ji turètu laikyti galimais provokatoriais, tarnaujančiais agresoriui, kadangi ju veiksmai ardo gynybos pastangas. Valstybė turètų aiškiai paskelbti, kad okupacijos metu jos gynybos politika yra pilietinė gynyba“. Žr.: Audrius Butkevičius, Mažos valstybes gynybos strategijos tezès, Cambridge, MA: The Albert Einstein Institution, 1994, p. 26.

${ }^{61}$ De Valk G. in cooperation with Niezing J., Research on Civilia -Based Defence, Amsterdam: SISWO, 1993 
jungos ultimatumui. Tikima, kad visuotinè ir besąlyginè gynyba turètų užkirsti kelią tokiai kapituliacinei situacijai pasikartoti. Be to, visuotinès gynybos principui pasirinkti įtakos turejjo Lietuvos politiniame diskurse vyraujanti neorealistinė jos geopolitinès situacijos interpretacija ir su ja susijusi modernistinė suvereniteto samprata, taip pat orientacija ị kaimyninių šalių, ypač Švedijos, patyrimą.

Straipsnyje aptartuose oficialiuose dokumentuose neabejojama, kad narystė NATO ir ES garantuos Lietuvos teritorinị saugumą, tačiau taip pat pabrěžiama, kad „globalinis dinamiškas vystymasis pateikia naujų iššūkių, pavojingų situacijų ir grèsmių“ (NSS), todèl visuotinis pilietinis pasipriešinimas ir dabartinèmis sąlygomis lieka universaliu atsaku į bet kokias grèsmingas aplinkybes.

\section{Baigiamosios pastabos}

Iš karto po nepriklausomybės pripažinimo Lietuvos nacionalinio saugumo sistemai žengiant pirmuosius žingsnius, įvairių šalių pilietinės gynybos teoretikai ir entuziastai vylèsi, kad Lietuva taps pirmaja šalimi pasaulyje, kurios gynyba bus grindžiama neginkluotu pilietiniu pasipriešinimu. Negalima sakyti, kad Lietuva visiškai nepateisino jų lūkesčių, pilietinės gynybos nuostatos įeina ịjos saugumo ir gynybos politiką. Pažymètina, kad nors visos rytų ir centrinės Europos šalys patyrèžmonių galios veiksminguma, tačiau tik Lietuva oficialiai pripažino jos pritaikymą ir perspektyvas. Dėmesys pilietiniam pasipriešinimui Lietuvos saugumo ir gynybos politiką reprezentuojančiuose dokumentuose išlieka gana unikaliu faktu šiuolaikinejje gynybos konceptualizavimo praktikoje pasaulyje.

Apžvelgusi trumpą pilietinès gynybos idejos atsiradimo bei kai kuriu jos žingsnių igyvendinimo Lietuvoje istoriją, nesiimu prognozuoti jos tolimesnès raidos. Apsiribosiu tik kai kurių tendencijų bei problemų, lydinčių pilietinės gynybos vystymąsi po Šaltojo karo, formulavimu.

Pilietinès gynybos teorija daugiausiai buvo vystoma Šaltojo karo laikotarpiu nedidelèse nebranduolinėse valstybèse. Konceptualiu ir pilietinès, ir karinès gynybos strategijos pagrindu buvo ir lieka neorealistinè tarptautinès sistemos samprata. Saugumą neorealizmas supranta kaip geopolitiškai sąlygotų nuolatinių grèsmių valstybei ir tautai identifikavimą ir jų neutralizavimą

politinèmis ir karinėmis priemonėmis. Pasaulis yra padalijamas į saugų, racionaliai valdomą tautinès valstybės vidų ir pavojingą anarchinę neprognozuojamą išorę, ị taikos ir grèsmės zonas. Būtent tokia tarptautinių santykių samprata remiasi visuotinès gynybos ir pilietinio pasipriešinimo idẻja Lietuvos nacionalinio saugumo pagrinduose ${ }^{62}$.

Neorealizmo sąvokomis konceptualizuojamoje tikroveje visuomenès konsolidavimo, jos mobilizavimo gynybai pagrindas yra bendrų, vienareikšmiškai apibrèžiamų grèsmių kolektyviniam (tautiniam) identitetui pripažinimas, jų konstravimas ir rekonstravimas ${ }^{63}$. Lietuvoje $1988-1991 \mathrm{~m}$. bendra, vienijančia visuomenę gynybai grèsme buvo Sovietų Sajungą, vèliau - nenumatoma ir neprognozuojama Rusija. 
Po Šaltojo karo, žlugus bipoliarinei pasaulio tvarkai bei intensyvejjant globalizacijai, riba tarp taikos ir grèsmès zonų praranda pastovumą, tampa paslanki. Aktualizuojasi naujos, demokratinėms valstybėms bendros grèsmès, susijusios su terorizmu, nelegalia migracija, žmogaus teisių pažeidimais. Keičiasi saugumo ir grèsmès sampratos, buvęs aiškus priešas netenka apibrèžtumo.

Lietuvos dalyvavimas euroatlantinėje integracijoje stiprina jos teritorinị saugumą, tačiau drauge silpnina simbolinị ryṣ̨̌ tarp tautos ir valstybès bei skatina tautinio identiteto eroziją. Grèsmėms netenkant vienamatiškumo, keičiasi visuomenę konsoliduojantys faktoriai, mažeja tautinès priklausomybės vaidmuo formuojantis kolektyviniam identitetui. Žmones vienijančiu faktoriumi tampa ne tautybé, o pilietybè, bendros politinès vertybès. Stiprų tautinị identitetą keičia pilietinis identitetas, kurị vokiečiu filosofas Jurgens Haberm pavadino konstituciniu patriotizmu ${ }^{64}$.

Šiomis globalaus vystymosi aplinkybėmis keičiasi ir pilietinio pasipriešinimo bei pilietinès gynybos turinys. Viena vertus, atgrasymas nuo agresijos, orientuotas i konkretų priešą, netenka prasmès. Tačiau, kita vertus, atsirandant naujiems iššūkiams bei pavojingoms situacijoms, visuotinis pilietinis pasipriešinimas nepraranda aktualumo, išlikdamas universaliu atsaku ị bet kokias grèsmes.

Dabartiniame demokratijos raidos etape pagrindiniu pilietinés gynybos objektu tampa fundamentalios pilietinès laisvès, kurių egzistavimo prielaida yra stipri pilietine visuomenè, jos vertybių ugdymas ir išsaugojimas. Drauge pilietinio pasipriešinimo sistemoje atgrasymas nuo potencialaus priešininko virsta pilietiškumo mokykla. Būtent šia kryptimi pastaraisiais metais pasuko pilietinès gynybos įkomponavimas ị Lietuvos saugumo sistemą. Tai patvirtina Pilietinio pasipriešinimo rengimo centro programa ir veikla.

${ }^{64}$ Haberm J., The Inclusion of the Other: Studies in Political Theory, Cambridge, Mass.: The MIT Press, 1998, p. 225-226. 